\title{
The Effectiveness web-based Educational Program on Optimal Use of Smartphones among Students with Nomophobia based on Self-EfficacyTheory: The Role of the Medical Librarian
}

\begin{abstract}
Background and Objective: Nomophobia is defined as the fear of being out of mobile phone contact and is considered a phobia of the modern age. The current study explored the effectiveness of the medical Librarian's web-based educational program on optimal use of smartphones among students with nomophobia based on self-efficacy theory.

Materials and Methods: This semi-experimental study applied random controlled clinical trial and before-after Design groups with a follow-up method. The population included all students of Bushehr University of Medical Sciences. Of the population, 98 students with high score nomophobia were selected as a sample. They were divided into two groups, control, and intervention, randomly. The intervention group received a web-based educational program, plus an electronic pamphlet. Data were collected in two steps. SPSS software was used to analyze data.

Results: The results indicated that the nomophobia score in an intervention group reduced significantly $(P<0.001)$, just two weeks after the intervention $(54.1 \pm 16.20)$ in comparison to the before (78.3 \pm 22.11$)$. Also, the average score of self-efficacy increased remarkably $(P<0.001)$, after the intervention $(36.3 \pm 4.20)$ than before $(30.8 \pm 4.79)$. The score of nomophobia and self-efficacy showed a significant difference between the control and intervention groups.

Conclusion: Health-based educations, especially web-based educations, can be considered a good solution during the pandemics for target audiences. The useful web-based educational program could have improved the recognition of the students toward nomophobia and increase their self-efficacy.

Keywords: Medical librarian, Distance education, Internet addiction disorder, Self-efficacy.

Paper Type: Research Article.
\end{abstract}

C Citation (Vancouver): Khosravi Z, Javadzade H, Mahmoodi M, Basirian-Jahromi R. The Effectiveness web-based Educational Program on Optimal Use of Smartphones among Students with Nomophobia based on Self-EfficacyTheory: The Role of the Medical Librarian. Iran J Health Educ Health Promot. Autumn 2021;9(3): 246-257.

- Citation (APA): Khosravi Z., Javadzade H., Mahmoodi M., Basirian-Jahromi R. (Autumn 2021). The Effectiveness web-based Educational Program on Optimal Use of Smartphones among Students with Nomophobia based on Self-EfficacyTheory: The Role of the Medical Librarian. Iranian Journal of Health Education \& Health Promotion., 9(3):246-257.
Zahra Khosravi

M.Sc. student, Department of Medical Library and Information Science, Faculty of Paramedicine, Bushehr University of Medical Sciences, Bushehr, Iran.

Homamodin Javadzade Assistant Professor, Department of Health Education and Health Promotion, Faculty of Health and Nutrition, Bushehr University of Medical Sciences, Bushehr Iran

Marzieh Mahmoodi

Assistant Professor, Department of Biostatistics, Faculty of Health and Nutrition, Bushehr University of Medical Sciences, Bushehr, Iran. Email: mahmoodi.marzieh@gmail.com, 00000003-4273-6086

Reza Basirian-Jahromi

* Assistant Professor, Department of Medical Library and Information Science, Faculty of Paramedicine, Bushehr University of Medical Sciences, Bushehr, Iran. (Corresponding Author). rezabj@gmail.com

Received: 2021/05/25

Accepted: 2021/07/24

Doi:10.52547/ijhehp.9.3.246 


\section{تأثير برنامه آموزشى مبتنى بر وب در استفاده بهينه از كوشىهاى تلفن همراه هوشمنل} در بين دانشجويان مبتلا به نوموفوبيا براساس نظريه خودكارآملدى: نقش كتابیار يزشكى

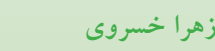

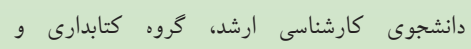

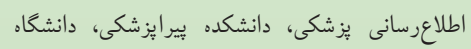

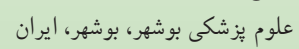

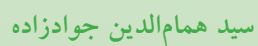
استاديار، كروه آموزش بهداشت و و ارتقاء سلامت، بداء

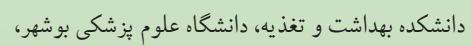
بوشهر، ايران.

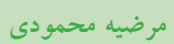
استاديار، كروه آمار زيستى، دانشكده بهداشت و تغذيه، دانشكاء علوم يزشكى بوشهر، بوشهر، ايران.

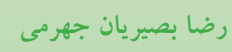

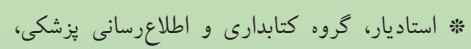

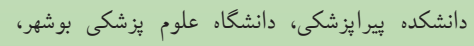
rezabj@gmail.com

بوشهر، ايران. (نو يسنده مسئول)

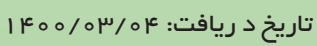

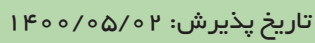

\section{5}

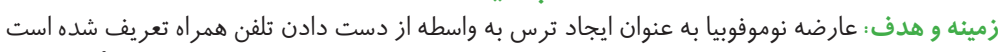

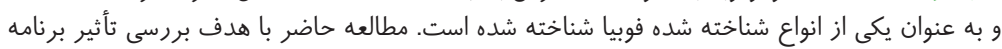

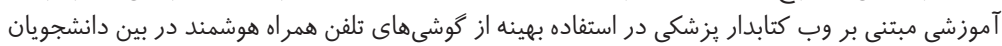

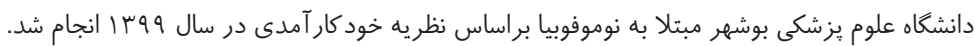

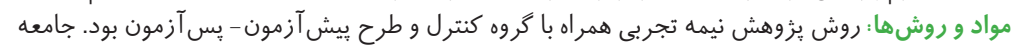

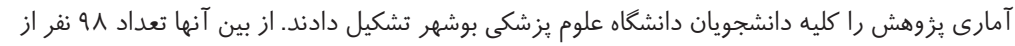

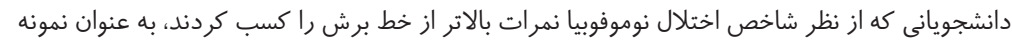

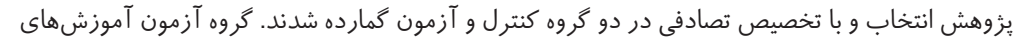

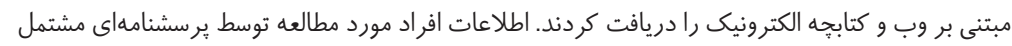

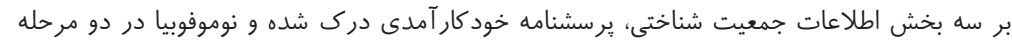

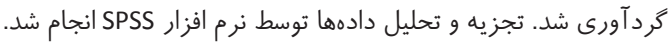

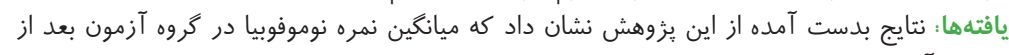

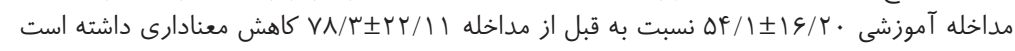

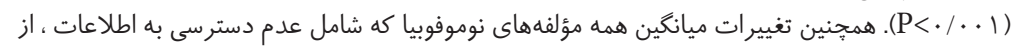

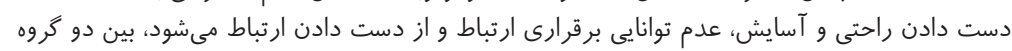

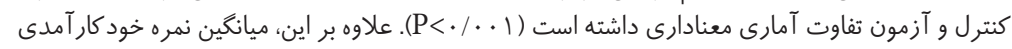

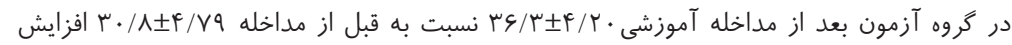

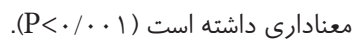

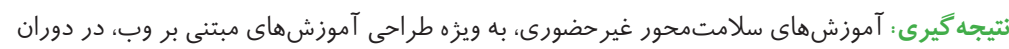

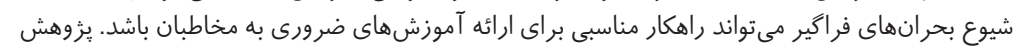

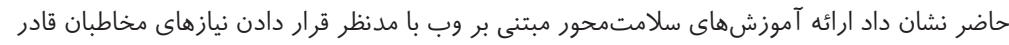

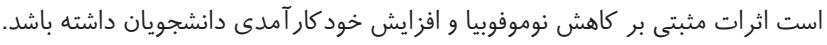

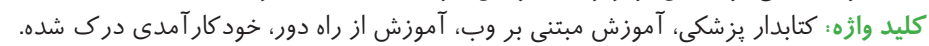

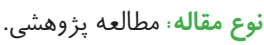

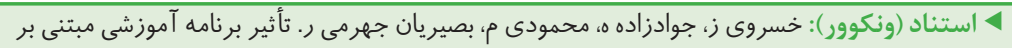

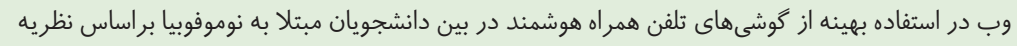

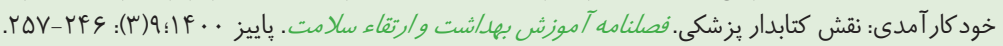

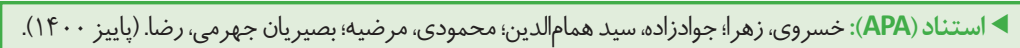

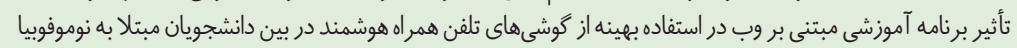

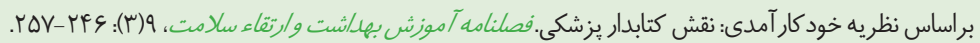


اين اختلال بيشتر توجه شود و راههاى پيشخيرى از آن شناسايى

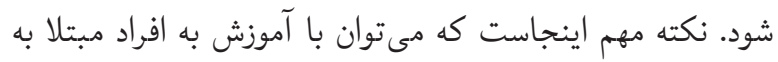
نوموفوبيا از شيوع و عوارض جسمى و روانى اين اختلال جلوكيرى

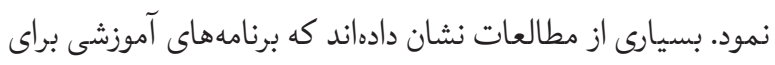
افراد مبتلا به نوموفوبيا باعث كاهش وابستكى به تلفن همراه شده

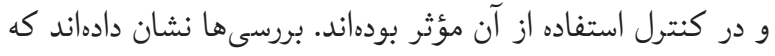
آموزش، در كاهش وابستكى به تلفن هوشمند، با موفقيت همراه بوده است (9، •1). در نتيجه آموزش نقش مهمى در كنترل بيمارى بها

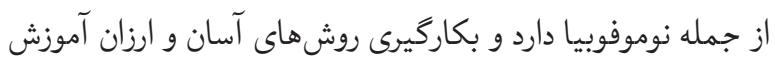
به بيماران از ضروريات يك جامعه است. روشهاى درمانى مانند

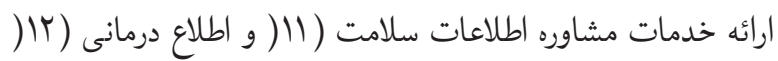
مى توانند كزينهایى مناسبى جهت كنترل بيمارى محسوب شوند كه

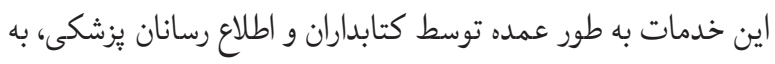
واسطه نقش و نوع عملكرد حرفهاى آنها در عصر حاضر، ارائه مى شودد. در عصر حاضر نقش كتابداران يزشكى، به واسطه بروز تغيير در

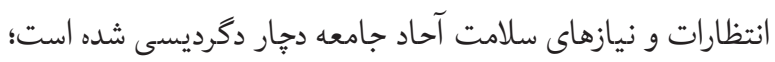
به نحوى كه موجب شده آنان جايكاه خود را به عنوان متخصصان و و ودار دردي

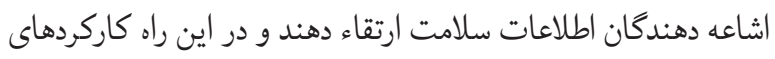
سنتى خود را با راهبردهاى جديدى جون مشاوره اطلاعات سلامت،

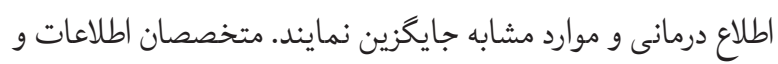
كتابدارانى كه رويكرد منفعلانه (حضور در محيط فيزيكى كتابخانه

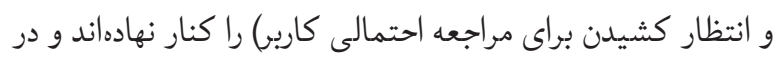

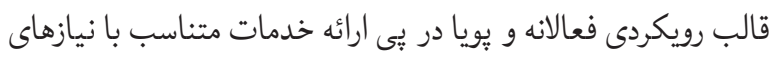
متنوع كاربران خويش (اعم از كادر درمان و افراد عادى جامعه) هستند.

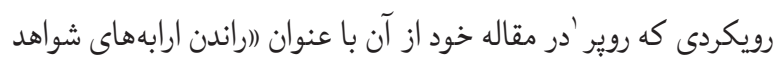
بالين به سوى بخشهاى گوناكون بيمارستانى و غير بيمارستانى")

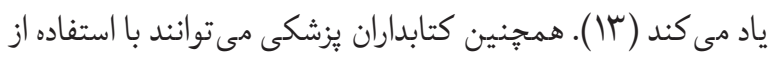

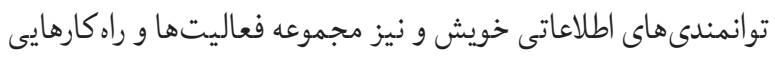

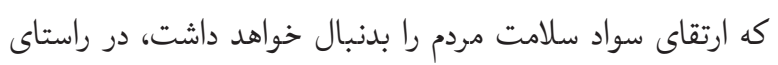

فناورىهاى اطلاعاتى و ارتباطى نقش مهمى در زندگى مردم ايفا مى كنند و جزء لاينفك زندگى امروزى شده است. فناورى هاى اطلاعاتى

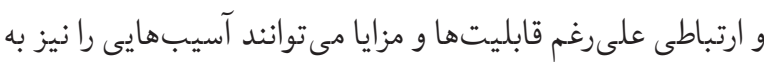

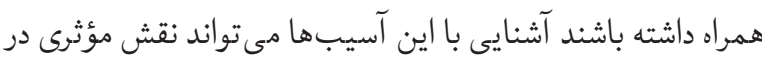

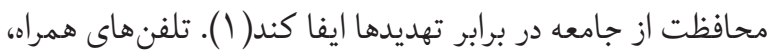
يكى از برجسته ترين نمونههاي متداول فناورى محسوب مى شوند.

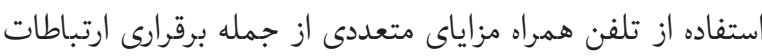

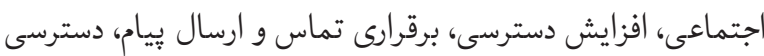

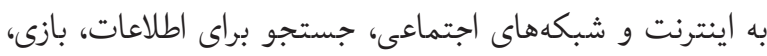
خريد آنلاين، تقويت امنيت و آسايش و غيره را به همراه دارد. اين جاين امر منجر به هذيرش گسترده و شكل گيرى نوعى فضاى هيجانى در

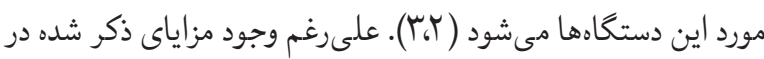

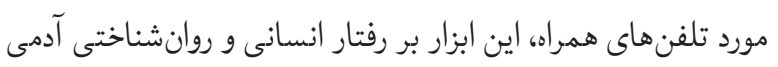

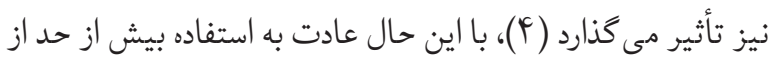

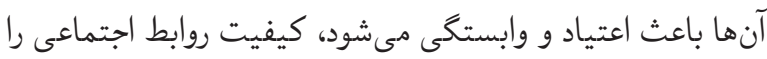
كاهش مىدهد و باعث قطع ارتباط با محيط اطراف مى شود (ه).

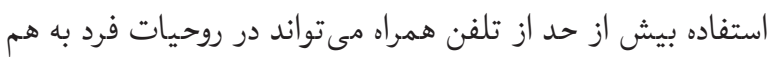
ريختكى ايجاد كند و به كوشه گيرى، كاهش روابط بين فردى و تعاملات اجتماعى، يرخاشكرى و احساس تنهايى منجر شود؛ اين

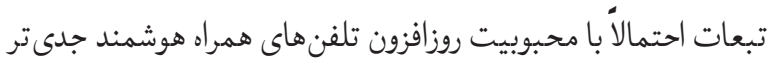
از كذشته نيز خواهد شد ( ()). بديده بى موبايل هراسى يا نوموفوبيا

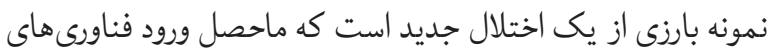

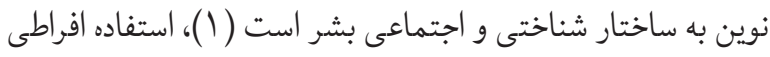

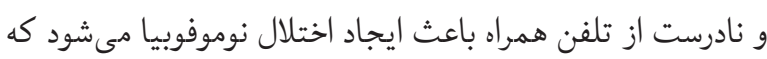
اين اختلال برخى مشكلات سلامت روان را با خود به همراه دارد (V).

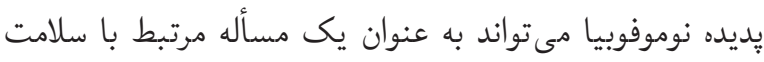

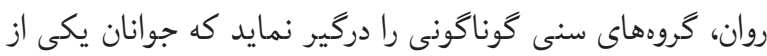
اين كروههاى در معرض تهديد محسوب ميىشوند. بررسى ها نشان داده است كه جوانان بدليل استفاده مكرر و بى رويه از تلفن همراه

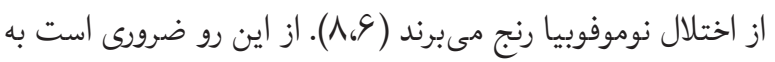


دارا بودن خود كار آمدى بالا باعث افزايش ساز كارى در زمان بروز تنش و فشارهاى روانى و همجِنين كاهش وابستكى به تلفن همراه

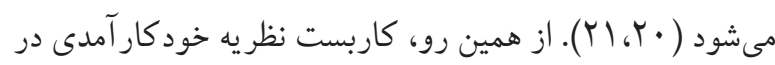
بين افراد مبتلا به نوموفوبيا مى تواند به احتمال زياد منجر به تغيير

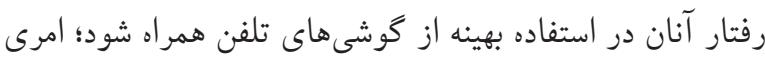

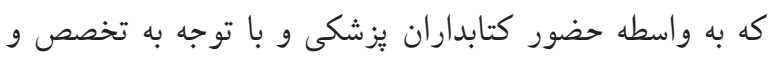

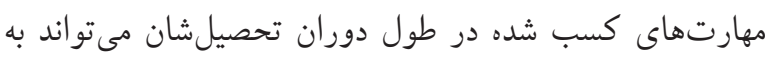

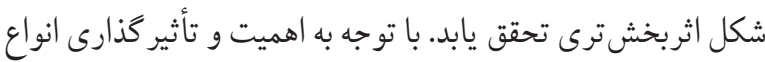

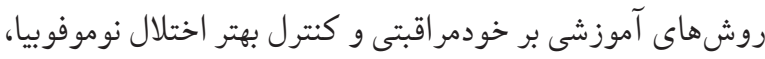

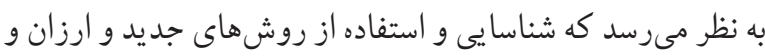
ارائه خدماتى همجِون مشاوره اطلاعات سلامت و اطلاع درمانى ارائه

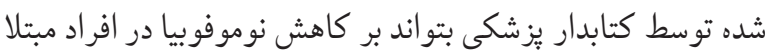

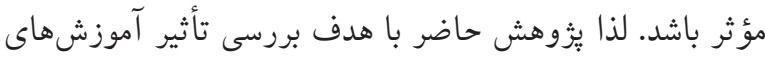

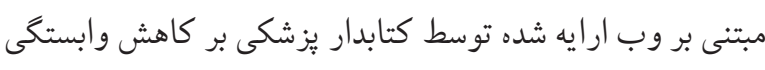

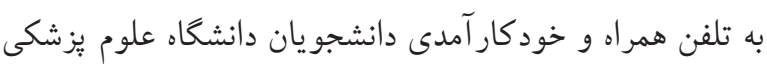
بوشهر در استفاده از تلفن همراه انجام بذيرفت.

مو اد و روش ها

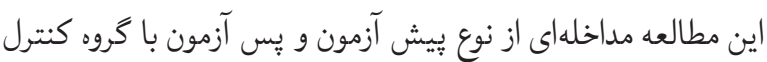
بود كه جامعه آمارى اين يثزوهش را كليه دانشجويان دانشكاه علوم يزشكى بوشهر در سال 99 إ تشكيل دادند.

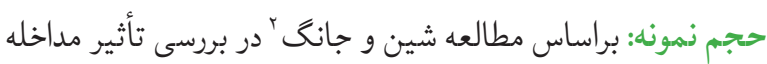

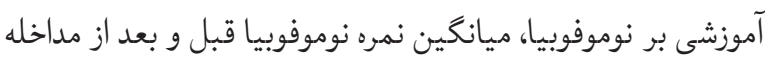

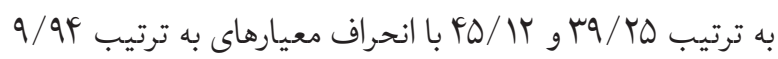

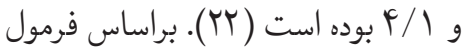

$$
n=\frac{\left(z_{1-\alpha / 2}+z_{1-\beta}\right)^{2}\left(\sigma_{1}^{2}+\sigma_{2}^{2}\right)}{\left(\mu_{1}-\mu_{2}\right)^{2}}
$$

و با در نظر گرفتن احتمال خطاى نوع اول و دوم به ترتيب ه.

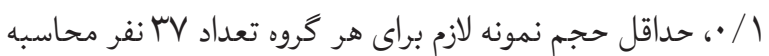

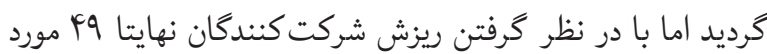
براى هر كروه برآورد كرديد.
افزايش سطح آكاهى هاى سلامت محور كامهاى اساسى بردارند تا

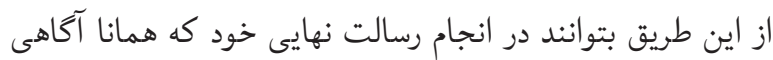
بخشى و كمك به بالا بردن سطح سلامت عموم افراد در جامعه از

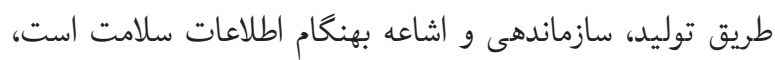

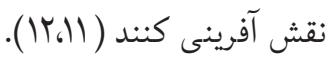

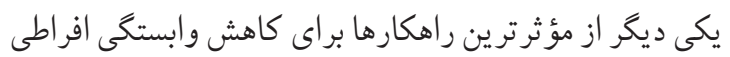

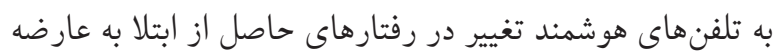

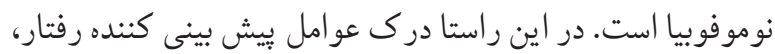

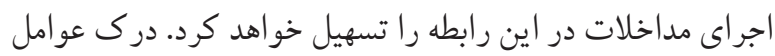

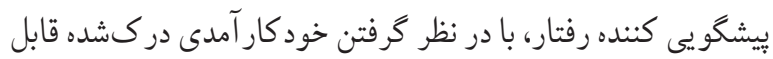

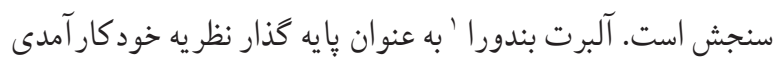

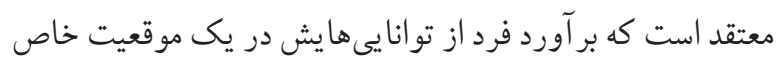
بر تصميم كيرى فرد در انتخاب فعاليت و اصرار به آن به شدت

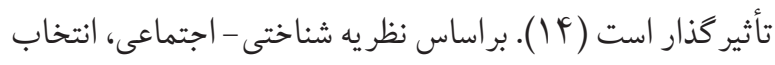

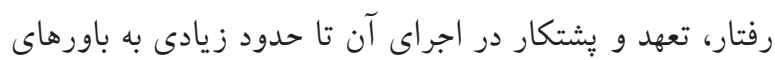

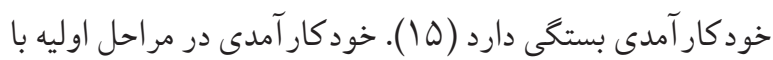
باور به اينكه (امن مىتوانم)) و (من فكر مى كنم)) رشد و كسترش

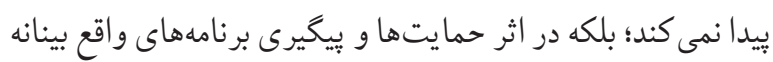

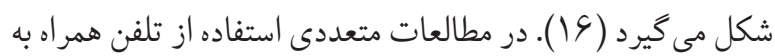

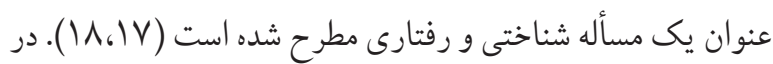

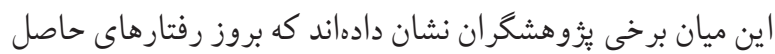

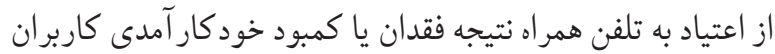

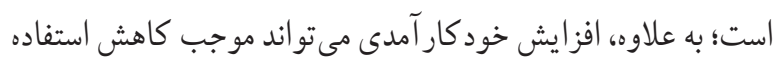

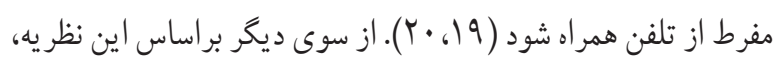

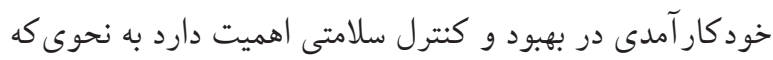
افر اد به طور ييوسته از طريق رفتارهاى خود هدايت مى شوند (19 (19). مطالعات در اين راستا نشان دادهاند كه افزايش خود كار آمدى تأثير زيادى بر كاهش اعتياد به تلفن همراه دارد. طبق مطالعات انجام

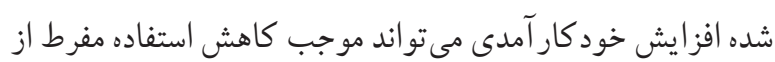

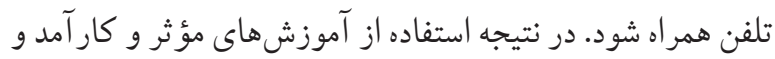


كروه آزمون و كنترل دو بار مورد ارزيابى قرار كرفتند. ارزيابى اول

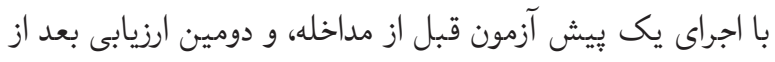

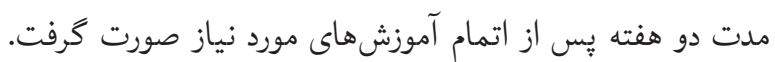

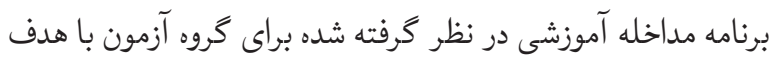

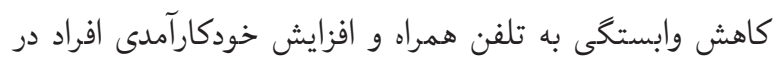
استفاده از تلفن همراه در قالب 9 جلسه آموزش مجازى تهيه شد. موضوع جلسات آموزشى شامل آشنايى دانشجويان وابسته به تلفن

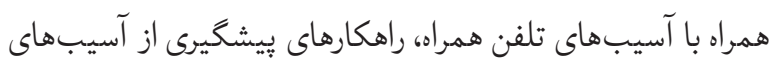

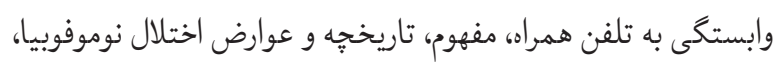

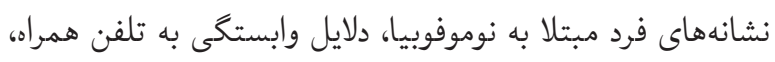

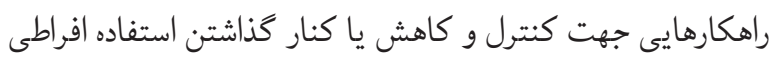

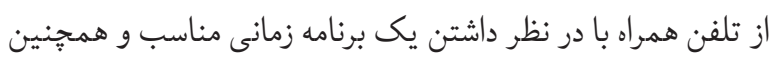

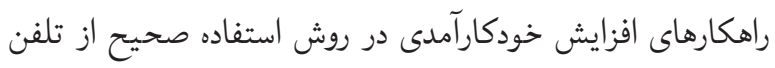
همراه به مدت دو هفته مدنظر قراركرفت.

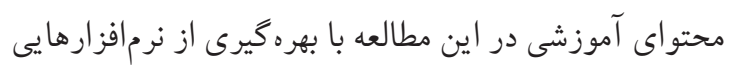

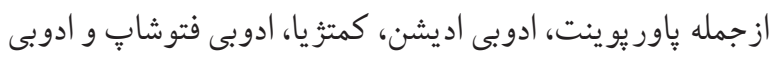

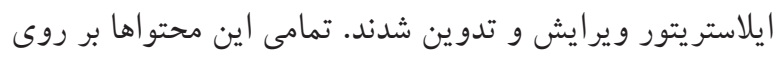

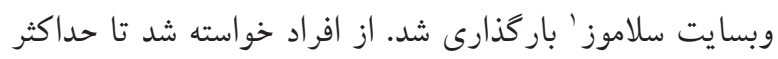

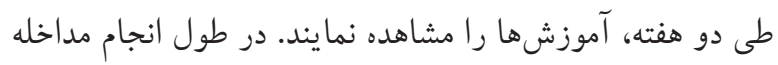

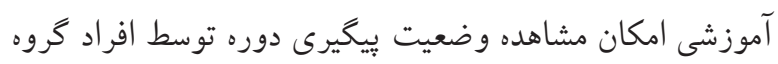

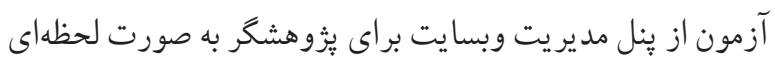

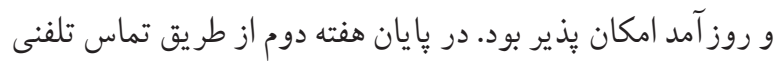

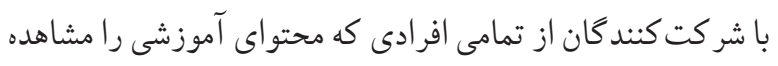

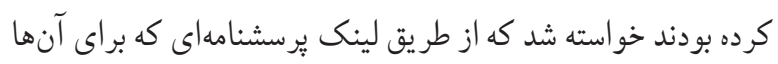

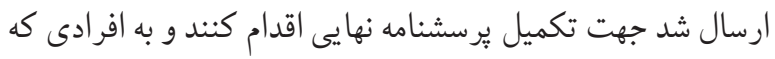

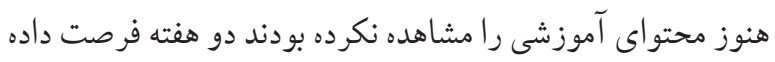

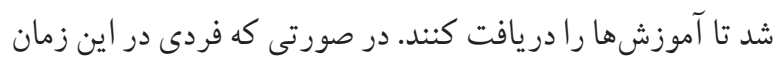

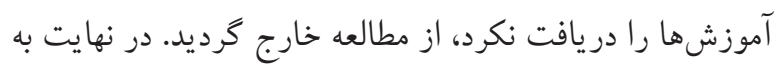

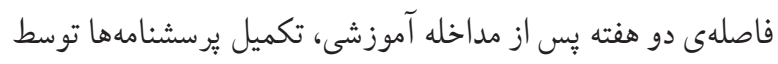

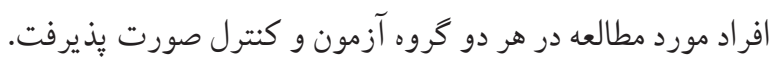

1. https://plus.salamooz.com
روش نمهونه كَيرى: در اين يُروهش از روش نمونه كيرى تصادفى طبقهاى استفاده شد كه دانشكدهها به عنوان طبقات نمونه كيرى در نظر كرفته شدند به طورى كه از هر دانشكده به تناسب جمعيت آن،

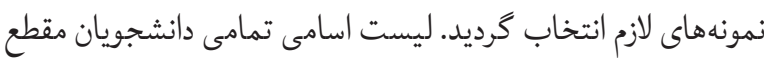
كارشناسى، كارشناسى نائيوسته، كارشناسى ارشد و دكترى عمومى إنى

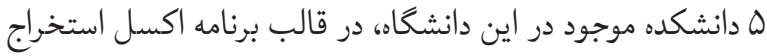

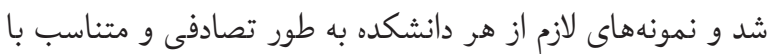

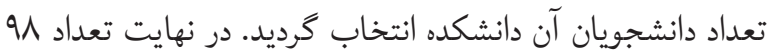
نفر از دانشجويان دانشكاه علوم يزشكى بوشهر به صورت تصادفى به عنوان شركت كندكان يروهش انتخاب شدند. معيارهاى ورود و خروج از مطالعه: معيارهاى ورود به مطالعه داشتن تلفن هوشمند و آشنايى كار با آن، تمايل به شركت درد مطالعه، دسترسى به اينترنت و تشخيص نوموفوبيا با استفاده از

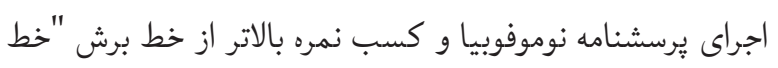

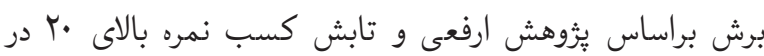

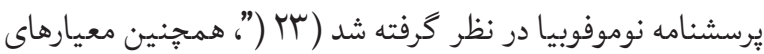

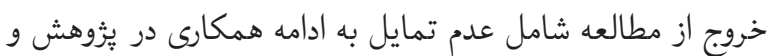
عدم مشاهده آموزشها توسط كروه آزمون بود.

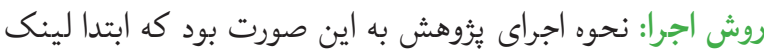
يرسشنامههاى باركذارى شده شامل اطلاعات جمعيت شناختى و سوالات

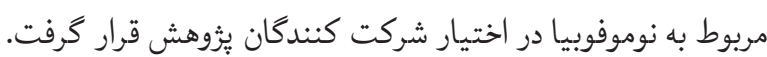
يّ إز تكميل برسشنامهها و بررسى اينكه جه تعداد دانشجو نمره بالاتر از خط برش را در برسشنامه نوموفوبيا كسب كردند، اين افراد

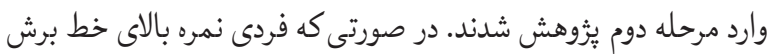
را در يُرسشناه نوموفوبيا كسب نكرده باشد از مطالعه خارج و يك دري فرد ديكر بهطور تصادفى از ليست دانشجويان آن دانشكده جايكزين شد. اين فرآيند تا رسيدن به تعداد نمونه لازم براى ورود به مطالعه دئه

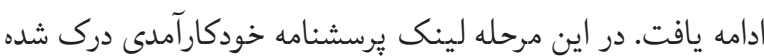
براى شركت كنندكان ارسال و يُرسشنامها توسط شركت كنندگًان

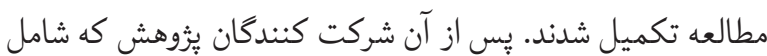
19 نفر بودند با تخصيص تصادفى در ץ كَروه 9 نفره جاى كَرفتند. 
را براى كل مقياس 9FD/ • و براى زير مقياسهاى ذكرشده به

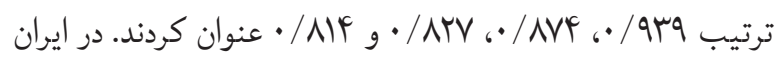

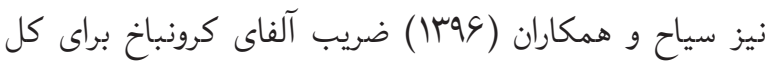

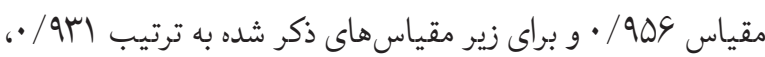

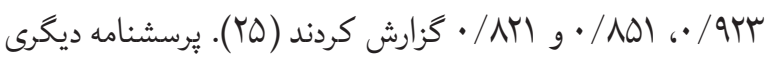

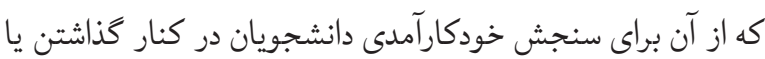

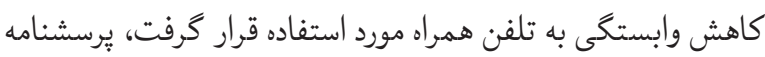

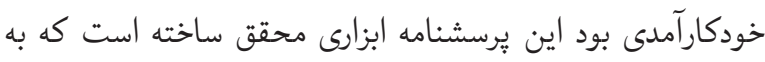

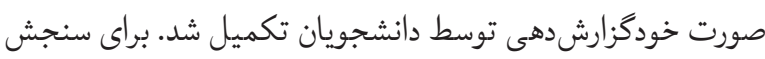

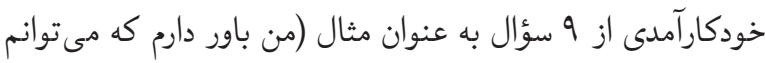

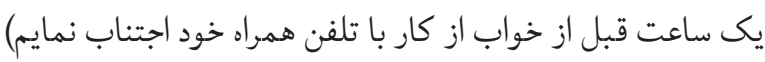

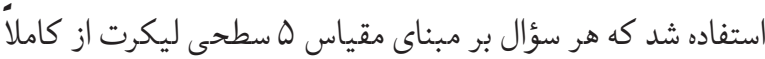

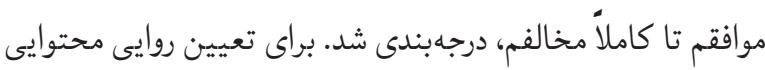

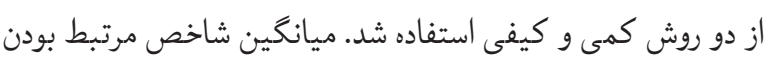

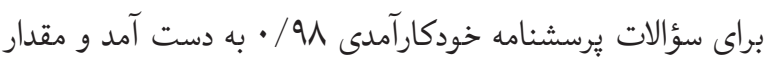

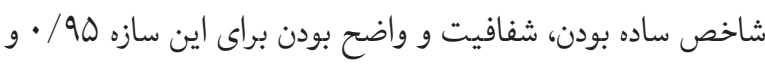

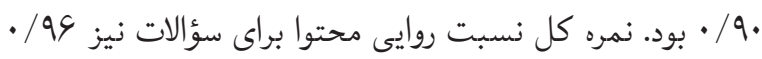

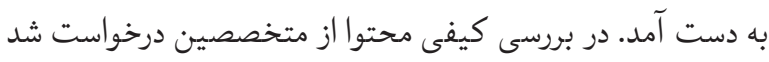

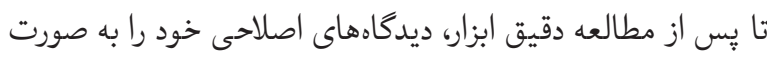

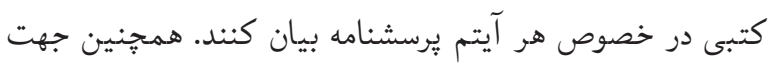

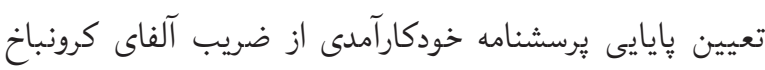

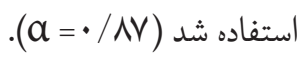

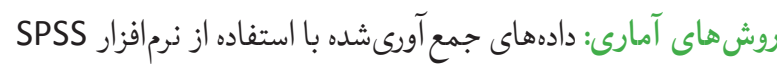

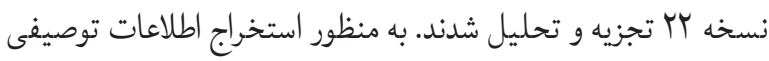
جدول فراوانى و شاخصهاى آمارى (ميانكين و انحراف معيار) ارائه

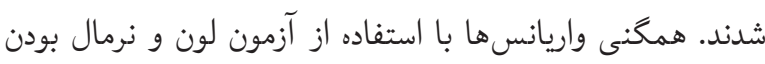

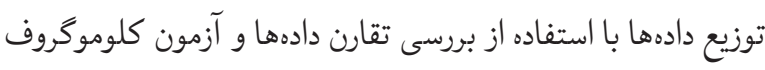

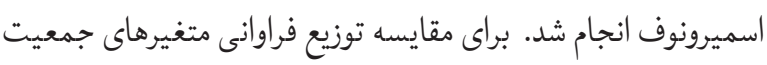

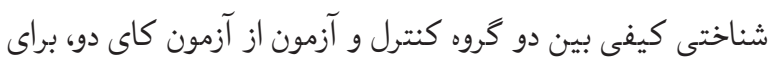

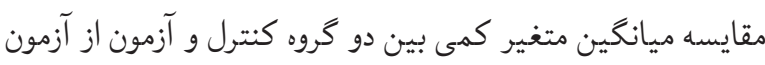

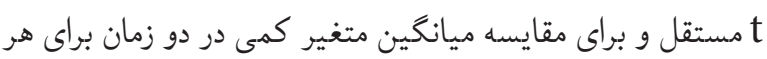

بس از انجام سنجش نهايى به جهت رعايت اخلاق در يُّوهش به

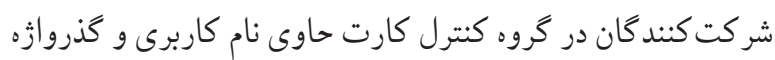

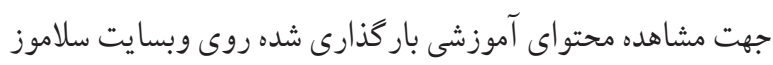

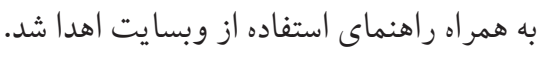

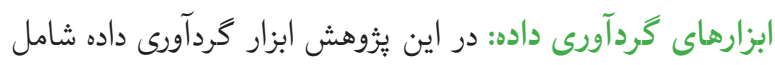

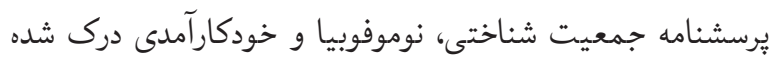

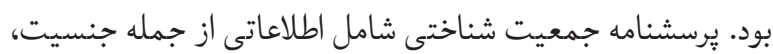
سن، دانشكده، مقطع تحصيلى، تعداد اعضاى خانواده، محل زندگى تئ،

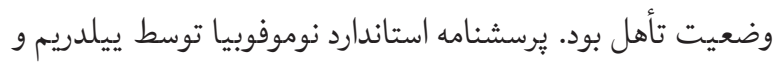

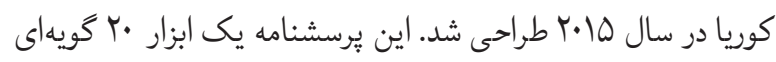
و شامل \& زير مقياس، () عدم دسترسى به اطلاعات شامل \& أسوال (نمونه سوال: من بدون دسترسى مداوم به اطلاعات از طريق تلفن

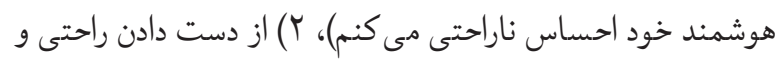

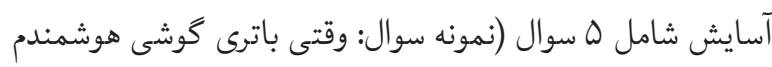
در حال اتمام است اين وضعيت مرا مى ترساند)، با) عدم توانايى

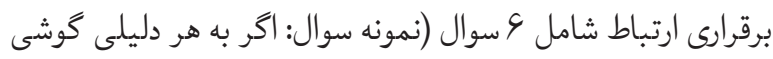

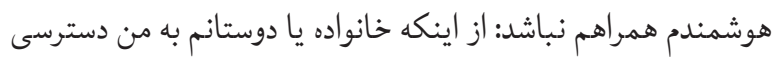

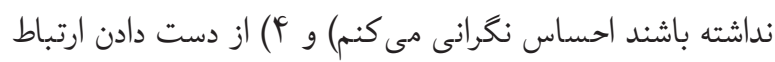
شامل ه سوال (نمونه سوال: اكر به هر دليلى كوشى هوشمندم همراهم

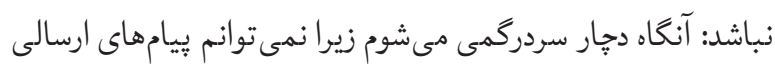

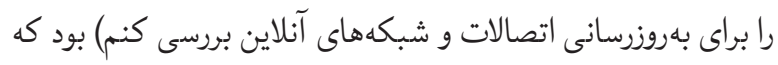

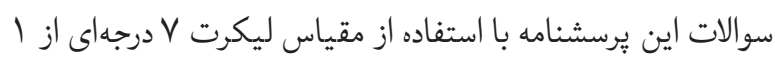

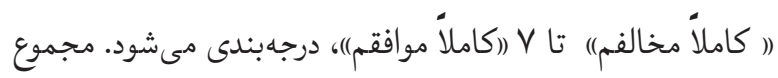

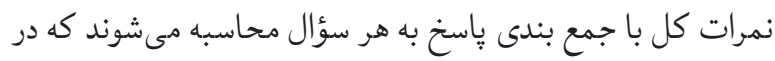

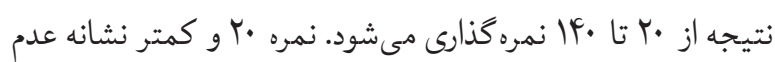

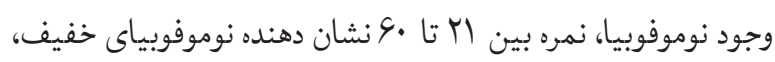

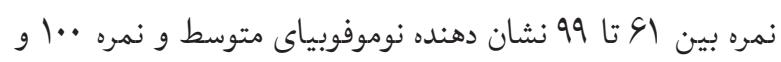
بيشتر نشان دهنده نوموفوبياى شديد مى باشد. روايى و وايايى اين اين

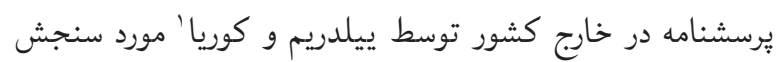

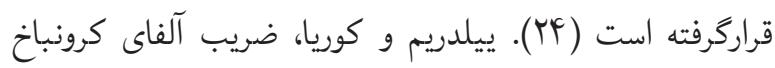


تحصيلى، سن، تعداد اعضاى خانواده) اختلاف آمارى معنادارى

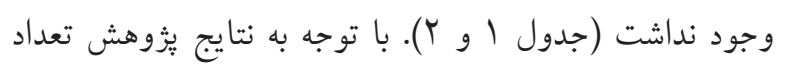

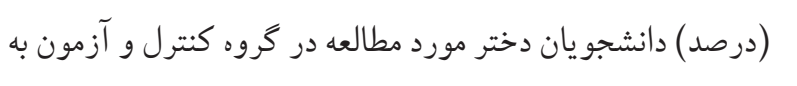

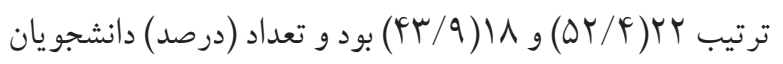

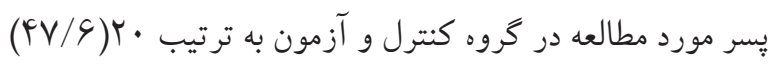

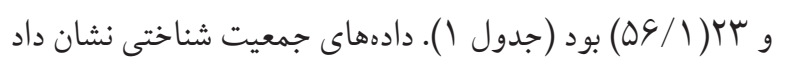

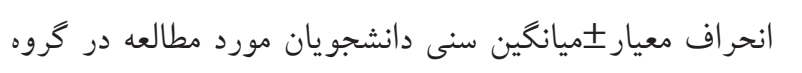
كنترل و آزمون به ترتيب (Y ) بود. انحر اف معيار ـميانگين تعداد اعضاى خانو اده دانشجويان مورد مطالعه در گروه كنترل و آزمون (Y) (Y)

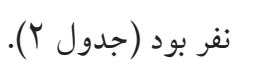

كروه از آزمون t زوجى استفاده شد. از تحليل واريانس اندازههاى تكرار شده نيز براى مقايسه تغييرات گرووه كنترل و آزمون استفاده كرديد. سطح معنادارى آزمونهاى آمارى ه • • • در نظر كرفته شد. يافته ها در طى مطالعه با ريزشهاى صورت گرفته در حين مداخله (1 نفر

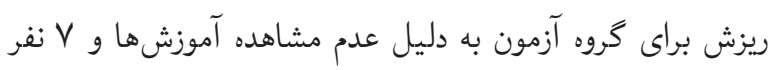

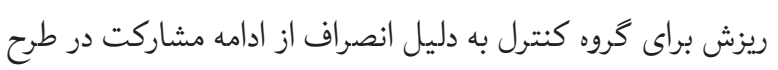

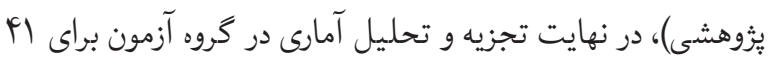

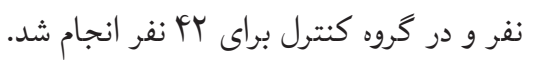

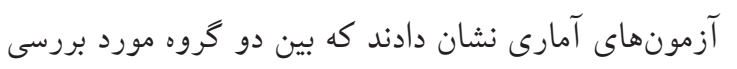
از نظر ويثگى هاى جمعيت شناختى (جنسيت، دانشكده، مقطع جدول ا : توزيع فراوانى و مقايسه متغير هاى كيفى واحدهاى يُوهش به تفكيى كَروه

\begin{tabular}{|c|c|c|c|c|}
\hline \multirow[t]{2}{*}{ P-value } & \multirow{2}{*}{ 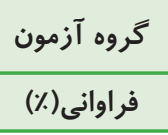 } & \multirow{2}{*}{ فروه كنترل } & \multirow{2}{*}{\multicolumn{2}{|c|}{ متغير (كيفى) }} \\
\hline & & & & \\
\hline \multirow{5}{*}{.1999} & $(r q / r) \mid r$ & $(Y \wedge / S) \mid r$ & يزشكى & \multirow{5}{*}{ دانشكده } \\
\hline & $(9 / 1) F$ & $(11 / 9) \Delta$ & دندانِز شكى & \\
\hline & $(r q / r) \mid r$ & $(r \wedge / \varsigma) \backslash r$ & يِيرايزشكى & \\
\hline & $(\mid F / G) G$ & $(\mid \mathcal{F} / \mu) G$ & بهداشت و تغذيه & \\
\hline & $(I V / I) \vee$ & $(\mid \varsigma / V) \vee$ & يرستارى و مامايى & \\
\hline \multirow{4}{*}{$\cdot / r \cdot F$} & $(\Delta r / V) r r$ & $(\mathcal{F} Y / q) \backslash \wedge$ & كارشناسى & \multirow{4}{*}{ مقطع تحصيلى } \\
\hline & $(r / q) r$ & $(\boldsymbol{r} / \wedge) r$ & كارشناسى نإييوسته & \\
\hline & $(V / \Psi) \Psi$ & $(\mid \mathcal{F} / \mu) \varsigma$ & كارشناسى ارشد & \\
\hline & $\left(M^{\mu} / l\right) \mid \mathcal{F}$ & $($ WN/I) Is & دكترى عمومى & \\
\hline \multirow{2}{*}{.$/ F q}$. & $(\mathcal{F} \sim / q) \backslash \wedge$ & $(\Delta Y / \mathcal{F}) r Y$ & دختر & \multirow{2}{*}{ جنسيت } \\
\hline & rr (DS/I) & $(\mathcal{F} V / \varphi) r$. & يسر & \\
\hline
\end{tabular}

جدول r. توزيع فراوانى و مقايسه متغيرهاى كمى واحدهاى يزوهش به تفكيك گروه

\begin{tabular}{|c|c|c|c|}
\hline \multirow{2}{*}{-سطح معنادارى } & كروه آزمون & كروه كنترل & \multirow{2}{*}{ متغير (كمى) } \\
\hline & انحراف معيار ذميانگين & انحراف معيار土ميانگين & \\
\hline$\cdot|\Delta F|$ & $r r / \varphi \pm r / F l$ & $r r / I \pm r / V V$ & سن \\
\hline$\cdot / \mathrm{Vrr}$ & $r / V \pm 1 / \Delta r$ & $r / \varphi \pm 1 / r \Delta$ & تعداد اعضاى خانواده \\
\hline
\end{tabular}


يافتها با توجه به جدول ب نشان داد كه ميانكين نمره خود كار آمدى در گروه كنترل ميانكين نمره خود كار آمدى در ش شده بعد از مداخله

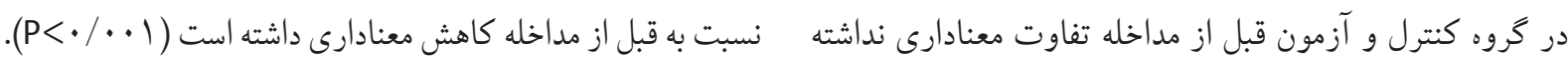

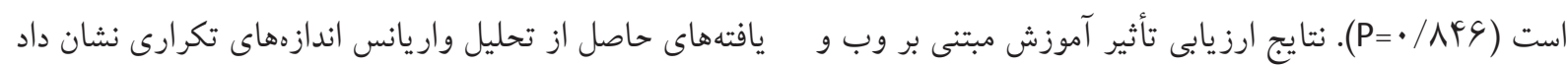

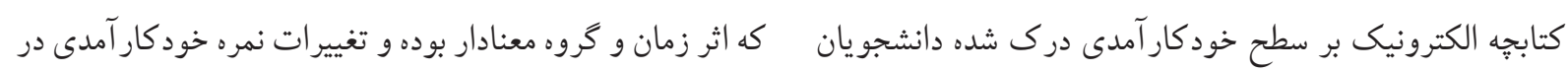

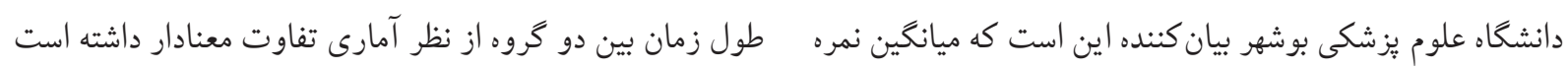

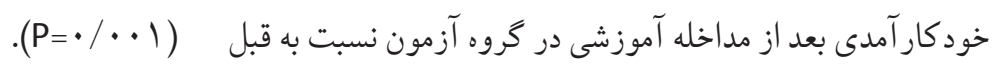

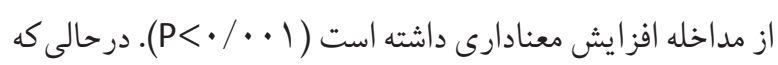

جدولَّ. تغييرات ميانكين نمرات خود كارآ مدى درى شده قبل و بعد از مطالعه به تفكيى دو كَروه

\begin{tabular}{|c|c|c|c|c|c|}
\hline \multirow{2}{*}{ سطح معنادارى؟ } & \multirow{2}{*}{ سطح معنادارىץ } & آزمون & كنترل & \multirow{2}{*}{ كروه و زمان } & \multirow{5}{*}{ خودكار آمدى درى شده } \\
\hline & & انحراف معيار \ميانگين & انحراف معيار \ميانگين & & \\
\hline \multirow{3}{*}{$\cdot / \cdots 1$} & - /NFs & $r \cdot / \Lambda \pm r / \vee q$ & س & قبل از مداخله & \\
\hline & $<\cdot / \cdot \cdot 1$ & $r \varphi / \mu \pm r / r$. & $r \wedge / I \pm s / r r$ & بعد از مداخله & \\
\hline & - & $<\cdot / \cdot \cdot 1$ & $<\cdot / \cdots 1$ & سطح معنادارى' & \\
\hline
\end{tabular}

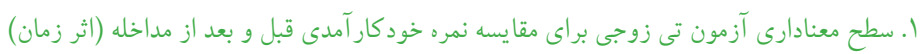

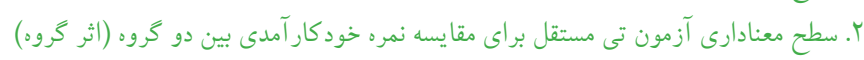

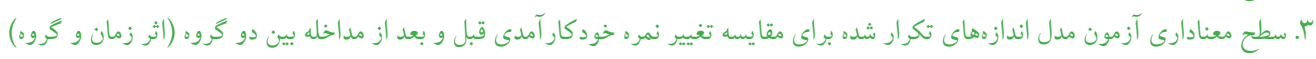

كنترل بعد از مداخله نسبت به قبل از مداخله افزايش معنادارى

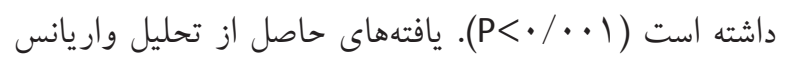

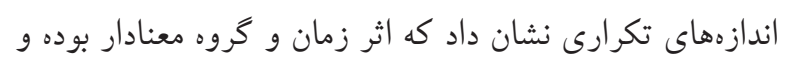

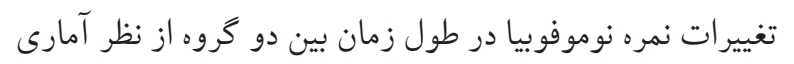

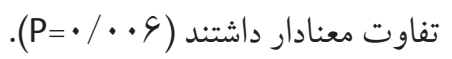

يافتها با توجه به جدول F أنشان داد كه ميانگين نمره نوموفوبيا

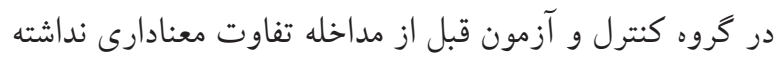

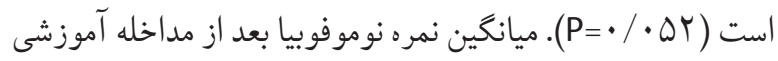

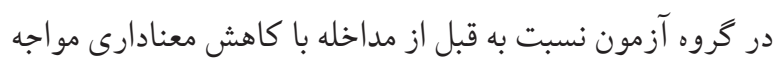

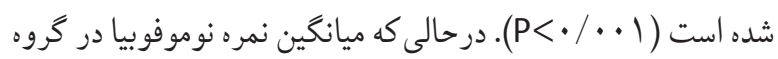

جدول عا. تغييرات ميانكَين نمرات نوموفوبيا قبل و بعد از مطالعه به تفكيك دو گروه

\begin{tabular}{|c|c|c|c|c|c|}
\hline \multirow{2}{*}{ سطح معنادارى؟ } & \multirow{2}{*}{ سطح معنادارى' } & آزمون & كنترل & كروه و زمان & \multirow{5}{*}{ نوموفوبيا } \\
\hline & & انحراف معيار土ميانكين & انحراف معيار土يميانگين & & \\
\hline \multirow{3}{*}{.$/ .4$} &.$/ \Delta r$ & $V \Lambda / r \pm r r / l l$ & $G N / q \pm r \mid / \mathcal{L}$ & قبل از مداخله & \\
\hline & $<\cdot / \cdot \cdot 1$ & $\Delta F /| \pm| G / r$. & $\Delta r / \mathcal{q} \pm r \mid / I r$ & بعد از مداخله & \\
\hline & - & $<\cdot / \cdot \cdot 1$ & $<\cdot / \cdot 1$ & سطح معنادارى' & \\
\hline
\end{tabular}

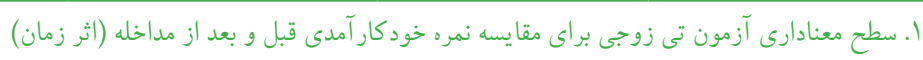

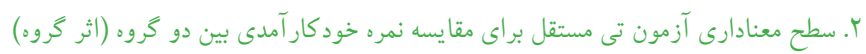

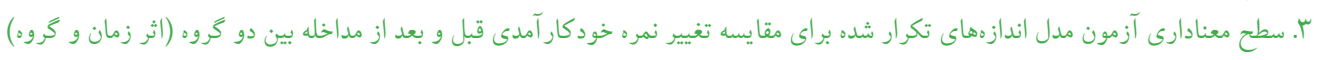

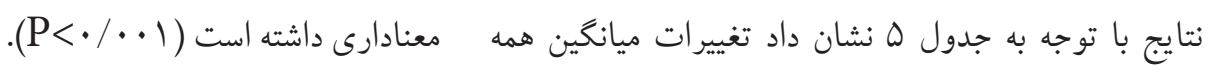

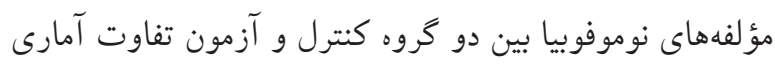


جدول ه. تغييرات ميانگين نمرات مؤلفههاى يرسشنامه نوموفوبيا قبل و بعد از مطالعه به تفكيك دو گروه

\begin{tabular}{|c|c|c|c|c|}
\hline \multirow{2}{*}{ سطح معنادارى } & بعد از مداخله & قبل از مداخله & \multirow{2}{*}{ زمان و كروه } & \multirow{2}{*}{ مؤلفههاى نوموفوبيا } \\
\hline & انحراف معيار土 ميانكين & انحراف معيار土 ميانكين & & \\
\hline \multirow{2}{*}{$<\cdot / \cdot \cdot 1$} & $11 / 9 \pm r / 9 r$ & $r \cdot / I \pm r / F r$ & آزمون & \multirow{2}{*}{ عدم دسترسى به اطلاعات } \\
\hline & $\mid \Lambda / \Lambda \pm \Delta / r \mu$ & $I V / r \pm \Delta / r r$ & كنترل & \\
\hline \multirow{2}{*}{$<\cdot / \cdots 1$} & $\mid F / \cdot \pm F / \Delta G$ & $\mid 9 / F \pm s / 91$ & 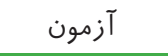 & \multirow{2}{*}{ از دست دادن راحتى و آسايش } \\
\hline & $r l / r \pm \Delta / q r$ & $1 V / F \pm s / 19$ & 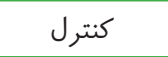 & \\
\hline \multirow{2}{*}{$<\cdot / \cdots 1$} & $1 \xi / \mu \pm \Delta / \mu \Delta$ & $r F / \cdot \pm q /{ }^{\prime} F$ & آزمون & \multirow{2}{*}{ عدم توانايى برقرارى ارتباط } \\
\hline & $r \Delta / \cdot \pm V / q r$ & $r Y / \cdot \pm q / T r$ & كنترل & \\
\hline \multirow{2}{*}{$<\cdot / \cdots 1$} & $11 / 9 \pm 0 / \cdot F$ & $\mid f / 9 \pm s / 9 q$ & 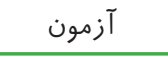 & \multirow{2}{*}{ از دست دادن ارتباط } \\
\hline & $|\wedge /| \pm V / \cdot \Delta$ & $|r / \mu \pm \Delta / \mu|$ & كنترل & \\
\hline
\end{tabular}

بحث و نتيجنه گيرى ن. نتايج اين مطالعه تأثير محتواى آموزشى ارائه شده توسط كتابدار ارتقاء سطح آكاهى افراد در استفاده درست از تلفن همراه را دارند.

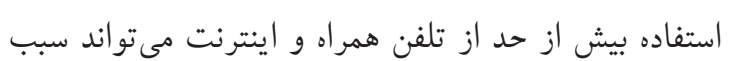

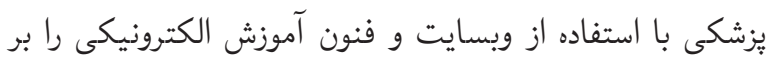

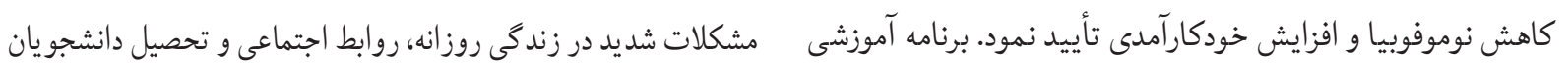

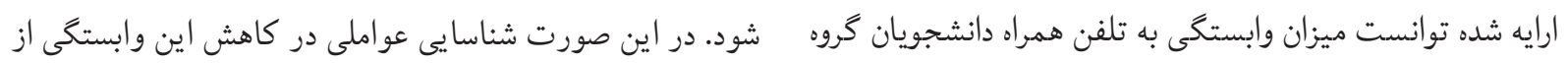

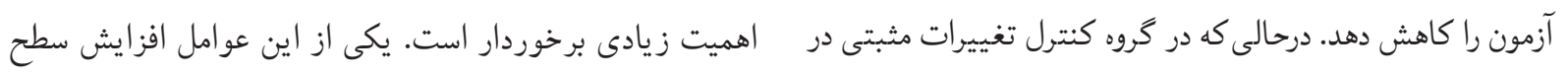

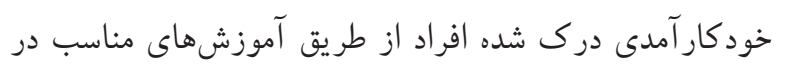

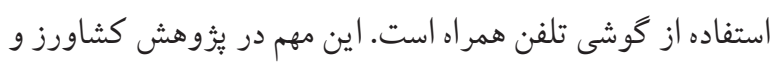

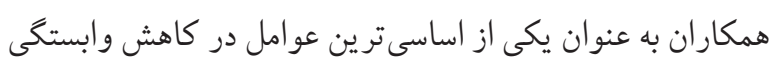

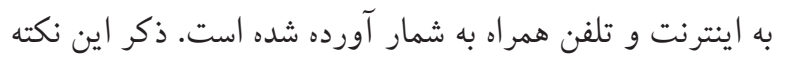

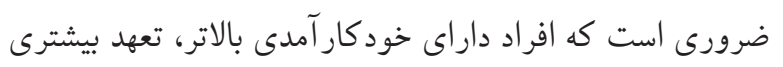

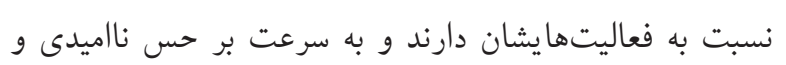

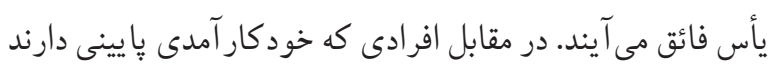

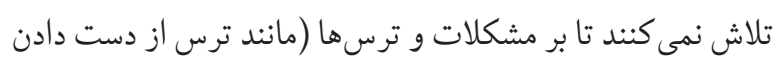

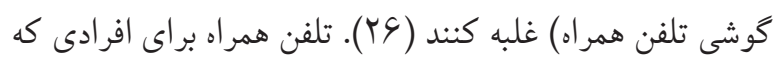

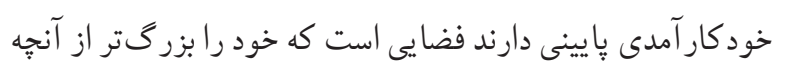

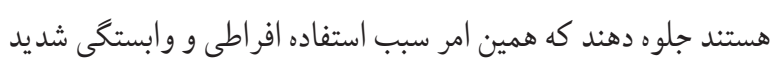

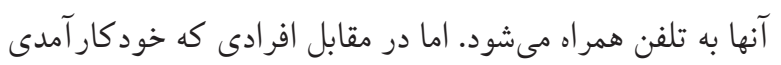

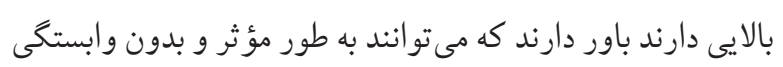

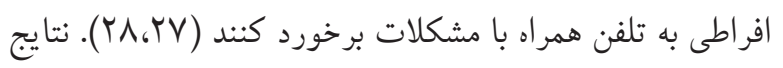

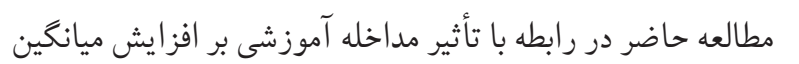

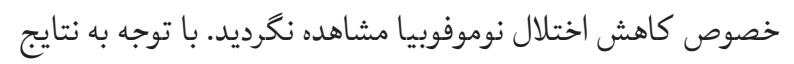
يزوهش در ارتباط با اختلال نوموفوبيا بين دو گروه كنترل و آزمون قبل از اجراى مداخله آموزشى تفاوت معنادارى وجود نداشت. اما ديا اجراى مداخله آموزشى موجب كاهش معنادارى در ميانخين نمره

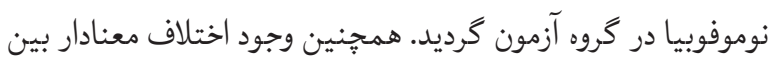

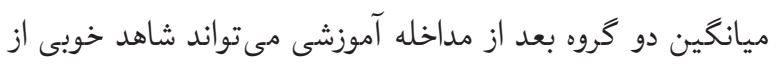
تأثير آموزش مبتنى بر وب بر كاهش معنادار نمرات همه مؤلفههاى

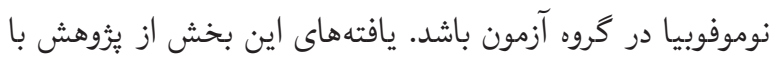

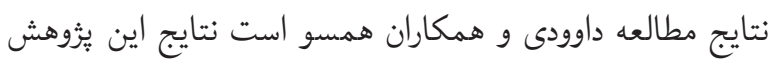

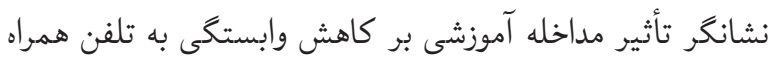

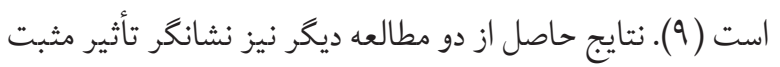

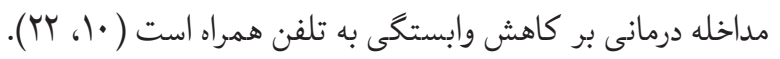

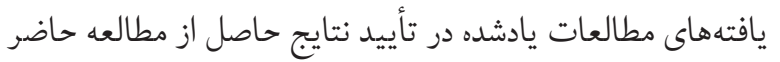

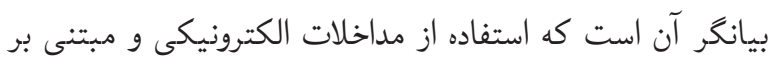
وب توسط كتابدار يزشكى در حوزه سلامت يُّانسيل لازم براى 
يزّوهش بود، كه به طبع مى توانست بر كيفيت دادهها تأثير بكذارد.

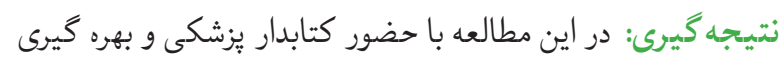

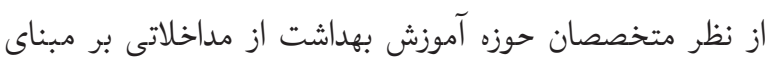

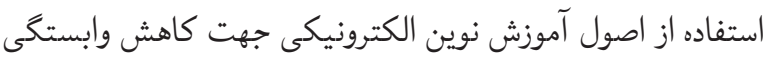

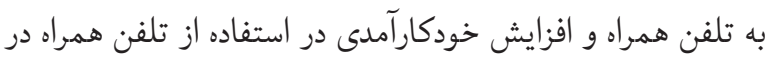
بين دانشجويان استفاده شد. براساس بررسىهاى انجام شده اين مطالعه نخستين يُوهشى است كه ضمن مشاركت فعال كتابدار

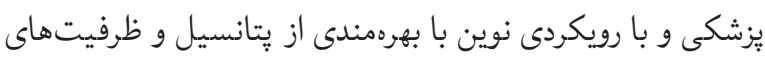

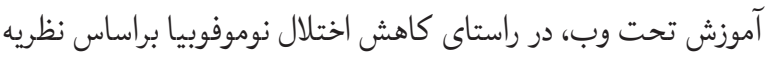

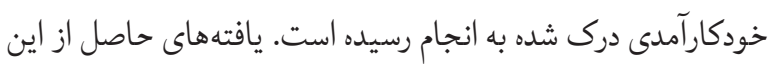

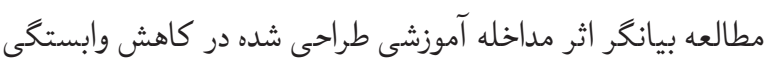
به تلفن همراه و افزايش خودكارآمدى در استفاده از تلفن همراه در دراح

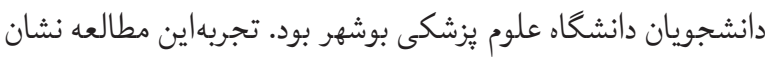

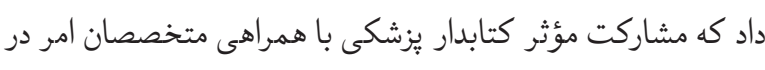

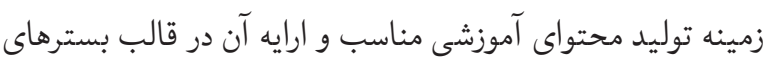

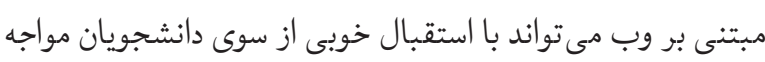

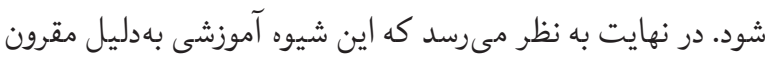

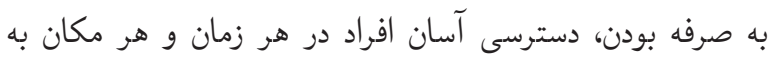

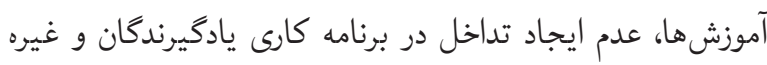

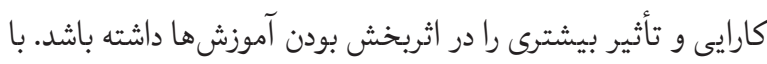

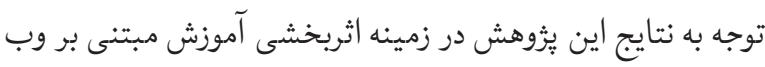
كتابدار يزشكى در زمينه كاهش وابستخى به تلفن همراها، بيشنهاد

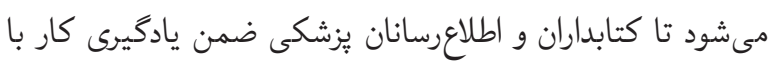

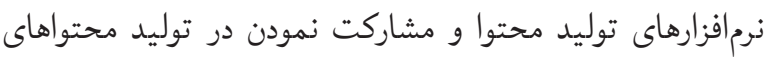

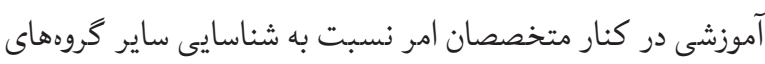

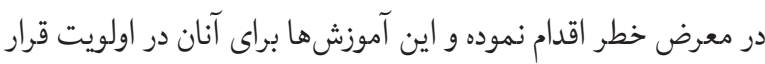

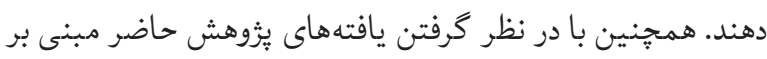

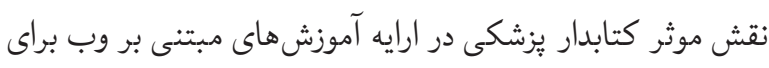

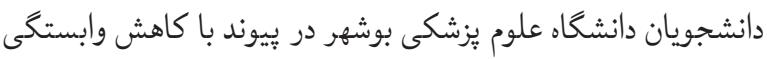

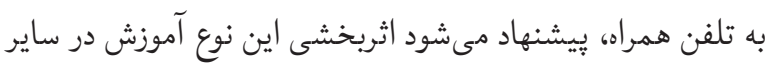

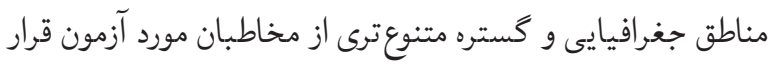

نمره خود كار آمدى در كروه آزمون نسبت به كروه كنترل نشان داد

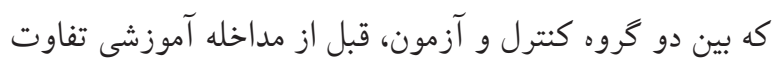

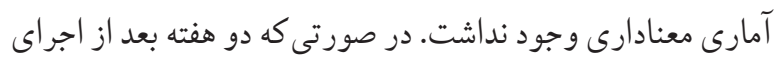
مداخله آموزشى خودكار آمدى دانشجويان در ميزان استفاده از تلفن إنان همراه در كروه آزمون افزايش معنادارى يافت.

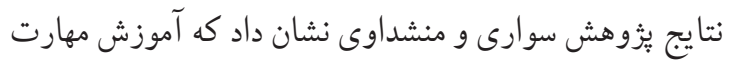

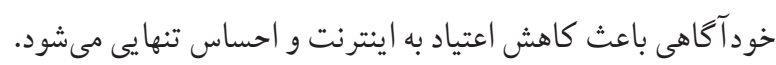

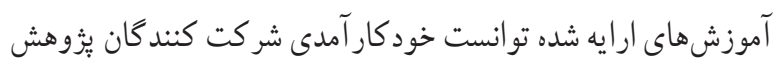
را افزايش دهد (9) . يافتهاي حسينى و همكار ان نيز همسو با بنتايج يُزوهش حاضر نشان داد كه هر دو روش آموزشى مورد استفاده،

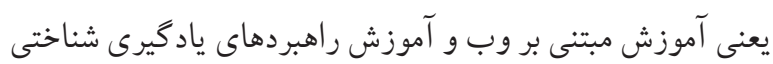

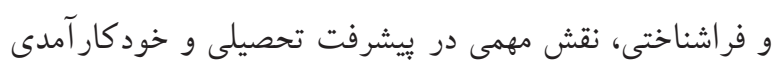
دانشجو يان داشتهاند (·r). بنابر آنجه كفته شد خودكار آمدى بر انتخاب رفتار و موقعيت

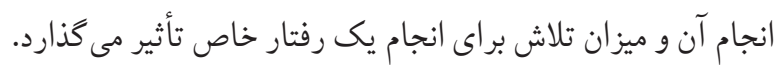

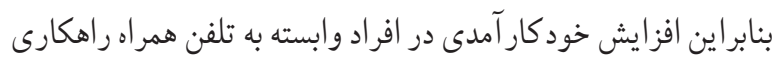

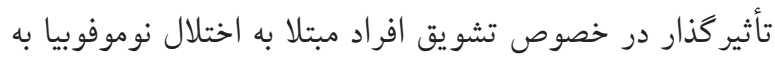
انجام فعاليتهاى خودمراقبتى از جمله كاهش استفاده از تلفن

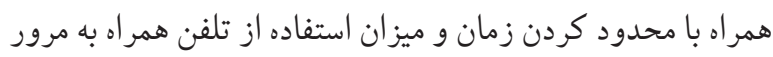

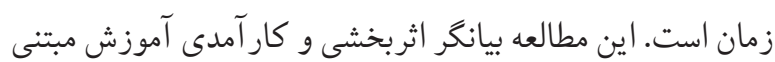

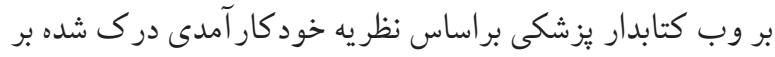
كنترل وابستخى به تلفن همراه بود. لذا بايد به راهكارهاى افز إيش برائ

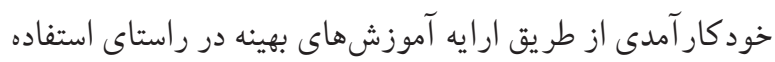

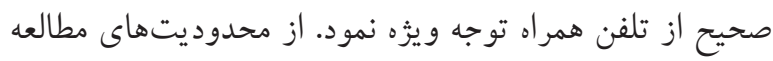

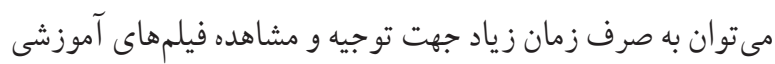

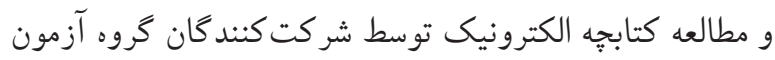
اشاره كرد. از طرفى محدود بودن مطالعه به دانشجو يان مبتلا به

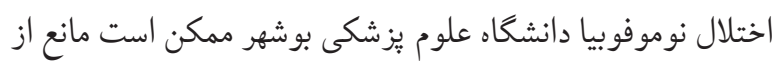

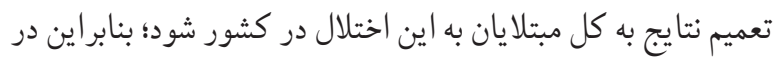

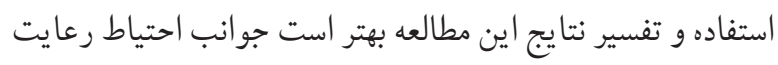

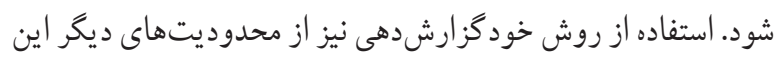




$$
\text { بوشهر، بوشهر، ايران با شماره سو 19F انجامشده است. }
$$

تضاد منافع: نويسندگان اظهار داشتند كه تضاد منافعى وجود ندارد. تشكر و قدردانى: يثوهشگران بر خود لازم مىدانند از معاونت آموزشى و معاونت تحقيقات و فناورى دانشخاه علوم يزشكى بوشهر تشكر و قدردانى نمايند. اين مقاله حاصل بخشى از يَايان نامه با عنوان (ابررسى تأثير برنامه آموزشى مبتنى بر وب كتابدار يزشكى در استفاده بهينه از كوشىهاى تلفن همراه هوشمند در بين دانشجويان مبتلا به نوموفوبيا براساس نظريه خودكارآمدى درسال 99 | : يك مداخله آموزشى)" مصوب دانشخاه علوم يزشكى بوشهر در سال 99"| مىباشد.

\section{References}

1. Askari S, Delavar, A, Farhangi AA. The relationship between mobile consumption pattern and "no mobile phobia" among mobile users in Tehran. Journal of Innovation and Creativity in Human Science. 2017;6(4): 197- 224.

2. zareipour M, Fattahi Ardakani M, Sotoudeh A, Tasouji Azari M. The Importance of Tele Education of Family Health Ambassadors in COVID -19 Prevention. Journal of Health Literacy. 2021;6(1):9-12.

3. Aliakbari R, Vahedian-Shahroodi M, Abusalehi A, Jafari A, TehraniH.Adigital-basededucationtoimproveoccupational health and ergonomic conditions of dentists: an application of theory of planned behavior. International Journal of Health Promotion and Education. 2020;58(5):268-81. https://doi.org/10.1080/14635240.2019.1687316

4. Savari Mombeni F, Babaei Heydarabadi A, Hatamzadeh $\mathrm{N}$, Sharhani $\mathrm{A}$. Investigating the effect of educational intervention based on Theory of Planned Behavior on the preventive behaviors regarding microbial and radiation complications of mobile phone in female students of secondary school. Iranian Journal of Health Education and Health Promotion. 2021;9(2):159-71. https://doi.org/10.52547/ijhehp.9.2.159

5. Gutiérrez-Puertas L, Márquez-Hernández VV, SãoRomão-Preto L, Granados-Gámez G, GutiérrezPuertas V, Aguilera-Manrique G. Comparative study of nomophobia among Spanish and Portuguese nursing students. Nurse Education in Practice. 2019;34:79-84. https://doi.org/10.1016/j.nepr.2018.11.010

6. Pontes H, CaplanS, Griffiths M. Psychometric Validation of the GeneralizedProblematicInternetUseScale2inaPortuguese Sample. Computers in Human Behavior. 2016;63, 823-833. https://doi.org/10.1016/j.chb.2016.06.015

7. King A, Valença A, Cardoso A, Sancassiani F, Machado S, Nardi A. "Nomophobia": Impact of Cell Phone Use Interfering with
كيرد و نتايج حاصل با يافتههاى يثوهش حاضر مقايسه شود. ملاحظات اخلاقى: اين مقاله حاصل بخشى از پاياننامه با عنوان (ابررسى تأثير برنامه آموزشى مبتنى بر وب كتابدار يزشكى در استفاده بهينه از كوشى هاى تلفن همراه هوشمند در بين دانشجويان مبتلا به نوموفوبيا براساس نظريه خودكارآمدى در سال 99 (1)، در مقطع كارشناسى ارشد، مصوب دانشخاه علوم يزشكى بوشهر، در سال 99سا با كد اخلاق به شماره IR.BPUMS.REC.1399.085 اخذشده از كميته اخلاق معاونت تحقيقات و فناورى دانشخاه علوم يزشكى بوشهر است.

حمايت مالى: اين يثوهش با حمايت مالى دانشخاه علوم يزشكى

Symptoms and Emotions of Individuals with Panic Disorder Compared with a Control Group. Clinical practice and epidemiology in mental health : CP \& EMH. 2014;10:28-35. https://doi.org/10.2174/1745017901410010028

8. Prasad M, Patthi B, Singla A, Gupta R, Saha S, Kumar JK, et al. Nomophobia: A cross-sectional study to assess mobile phone usage among dental students. Journal of Clinical and Diagnostic Research. 2017;11(2): 34-39. https://doi.org/10.7860/JCDR/2017/20858.9341

9. Davoudi R, Manshaee G, golparvar M. Comparison of the Effectiveness of Cognitive-Behavioral Therapy, Emotion focused therapy and Adolescent-centered Mindfulness Therapy on Nomophobia Symptoms and Sleep Quality of Girls with Nomophobic Symptoms. Iranian Journal of Psychiatric Nursing (IJPN). 2020;7(5):63-71

10. Mohammadi Nasab N, Manshaei G, Nadi MA. The effectiveness of reality therapy on self esteem and symptoms of mobile phobiaSecondaryschoolstudents with mobile phobia.6th International Conference on Psychology of Education Sciences and Lifestyle. 2020 .[In Persian] https://doi.org/10.5812/ijpbs.109291

11. Shahrzadi L, Ashrafi-rizi H. Health Information Consulting: Key Role of medical Librarians . J Med Educ Dev. 2016; 9 (21) :1-4 .

12. Zeinali V, Riahinia N. Information Therapy Services in Educational Hospitals: a Feasibility Study in Educational Hospitals of Shahid Beheshti University of Medical Sciences. 2015.

13. Roper T. The impact of the clinical librarian: a review. Journal of EAHIL L-1841-0715. 2015; 11, 19-22.

14. Sagone E, De Caroli M. E, Falanga R, Indiana ML. Resilience and perceived self-efficacy in life skills from early to late adolescence. International Journal of Adolescence and Youth. 2020; 25(1), 882-890. 
https://doi.org/10.1080/02673843.2020.1771599

15. Bozzato P, Longobardi C, Fabris MA. Problematic gambling behaviour in adolescents: prevalence and its relation to social, self-regulatory, and academic self-efficacy. International Journal of Adolescence and Youth. 2020;25(1):907-919. https://doi.org/10.1080/02673843.2020.1772842

16. Amirizadeh $S$, Shakerinejad G, Shahri P, Saki malehi A. Application of Self-Efficacy Theory in Nutrition Education for Weight Control in Obese and Overweight Female High School Students. Iran J Health Educ Health Promot. 2016; 4 (2):139-148. https://doi.org/10.18869/acadpub.ihepsaj.4.2.139

17. Pourrazavi S, Alan Verdipour H, Topchian A. Determination of the predictive role of self-regulation and self-control on intemperate use of cell phones by students. Avicenna Journal Of Clinical Medicine (Scientific Journal of Hamadan University Of Medical Sciences and Health Services). 2015;22(2) (SN 76):152-160.

18. Eide TA, Aarestad SH, Pallesen S, Andreassen CS, Bilder RM. Smartphone restriction and its effect on subjective withdrawal related scores. Frontiers in Psychology. 2018; 9. https://doi.org/10.3389/fpsyg.2018.01444

19. Chiu SI. The relationship between life stress and smartphone addiction on taiwanese university student: $A$ mediation model of learning self-Efficacy and social selfEfficacy. Computers in Human Behavior. 2014; 34, 49-57. https://doi.org/10.1016/j.chb.2014.01.024

20. Lee YK, Chang CT, Cheng Z.H, Lin Y. How Social Anxiety and Reduced Self-Efficacy Induce Smartphone Addiction in Materialistic People. Social Science Computer Revie.2016; 36(1), 36-56. https://doi.org/10.1177/0894439316685540

21. Darasian Salmasi A, Rezakhani S. The contribution of self-efficacy and sensation-seeking in predicting internet addiction in girls. Women's Studies Sociological and Psychological. 2019; 17(3): 31-56.

22. Shin JH, Jang M. Effect of Group Sandplay Therapy to be Addicted Youth's Addiction Levels and Anxiety. Journal of Symbols \& Sandplay Therapy. 2017; 7, 39-55. https://doi.org/10.12964/jsst.160002

23. Sedighi arfaee F, Tabesh R. The effectiveness of life skills training on loneliness and social competence of girl adolescents with symptoms of nomophobia. Rooyesh. 2021; 9 (12) :33-42. [In Persian]

24. Yildirim C, Correia A-P. Exploring the dimensions of nomophobia: Development and validation of a self-reported questionnaire. Computers in Human Behavior. 2015;49:130-137. https://doi.org/10.1016/j.chb.2015.02.059

25. Sayah S, Ghadami A, Azadi F. Psychometric properties of the nomophobia questionnaire (NMP-Q) among Iranian students. Psychometry.2018;6:7-25.

26. Keshavarz D, Keshavarz AreR, Mousavi AM. The Comparison of Coping Strategies and Self-Efficacy in Internet Addiction Normal Users. Quarterly Journal of Counseling and Psychotherapy. 2015;4(15). https://doi.org/10.1057/9781137465078_3

27. Morovati Z, Yadgari R. Comparison of loneliness and coping self-efficacy in cell phone addicted and normal female college students. Journal of Psychological Achievements (JOURNAL OF EDUCATION \& PSYCHOLOGY). 2020;26(2 (22) ), 243-262.

28. Mohebi Amin A, Rabiei M. Study of the Relationship between Self-Efficacy Beliefs and Creative Teaching in Mashhad Nursing and Midwifery Faculty. Research in Medical Education. 2019;11(1):10-9. https://doi.org/10.29252/rme.11.1.10

29. Sevari K, Manshedavi S. The efficacy of self-awareness training on reduction of internet addiction and loneliness and increase of self-efficacy. Clinical psychology studies. 2016;6(22):163-179.

30. Hosseini T, torabi SS, shayan N, Ismaeel Poor M, Ashoori J. Comparing the effects of web-based teaching and cognitive and metacognitive learning strategies on nursing students' academic achievement and self-efficacy, Islamic Azad University, pishva branch. interdisciplinary journal of virtual learning in medical sciences (IJVLMS). 2015;6(2):110. 